\title{
MCAM wt Allele
}

National Cancer Institute

\section{Source}

National Cancer Institute. MCAM wt Allele. NCI Thesaurus. Code C54308.

Human MCAM wild-type allele is located in the vicinity of $11 \mathrm{q} 23.3$ and is approximately 9 $\mathrm{kb}$ in length. This allele, which encodes cell surface glycoprotein MUC18 protein, plays a role in cellular adhesision, signal transduction and development. 